\title{
ANALISIS RUANG TERBUKA HIJAU (RTH) DARI ASPEK KETERLAKSANAAN FUNGSI SOSIAL DI KOTA MAKASSAR
}

\author{
Aris Sakkar Dollah; Rasmawarni; Andi Teddy M. \\ Dosen Prodi Arsitektur, Fakultas Teknik Universitas Muhammadiyah Makassar \\ Dosen Prodi Arsitektur, Fakultas Teknik Universitas Muhammadiyah Makassar \\ Dosen Prodi Arsitektur, Fakultas Teknik Universitas Muhammadiyah Makassar \\ risdollah@gmail.com,rasmawarninur@gmail.com, mappateddy@yahoo.com
}

\begin{abstract}
ABSTRAK
Penelitian ini bertujuan untuk menganalisis jenis dan keterlaksanaan fungsi sosial Ruang Terbuka Hijau (RTH) di Kota Makassar. Penelitian ini dilakukan dengan metode survei dengan analisis deskriptif. Data dikumpulkan dengan teknik observasi, wawancara terstruktur dan kuisioner. Hasil penelitian menunjukkan bahwa jenis RTH yang ada di Kota Makassar mayoritas dalam bentuk lapangan, sedangkan keterlaksanaan fungsi sosial RTH lebih didominasi oleh aktivitas olah raga. Unit RTH dengan keterlaksanaan fungsi sosial tertinggi terdapat di RTH Kompleks Lapangan Karebosi sedangkan yang terendah terdapat di RTH Taman Pattimura. Tingkat keterlaksanaan fungsi berdasarkan analisis skalogram berada pada angka 35 persen, tergolong masih rendah.
\end{abstract}

Kata Kunci : Ruang Terbuka Hijau (RTH), jenis RTH, fungsi sosial RTH.

\section{PENDAHULUAN}

Secara psikologis keadaan lingkungan disekitar manusia mempengaruhi keadaaan fisik dan mentalnya, untuk itu lingkungan yang sehat perlu dikembangkan dalam kehidupan masyarakat terutama dikota-kota besar, dimana akibat perkembangan fisik kota yang demikian pesat dan kurang terkendali berakibat hampir semua lahan perkotaaan dipergunakan untuk mendirikan bangunan dan fasilitas - fasilitas penunjang kota dan salah satu komponen persyaratan kota menjadi lingkungan yang sehat adalah tersedianya RTH yang cukup.

Idealnya sebuah kota memiliki RTH minimal $30 \%$ dari total luas kota, mengacu pada KTT Bumi di Rio de Janeiro, Brazil (1992), dan dipertegas pada KTT Johannesburg, Afrika Selatan (2002) (Kuswartojo 2006), juga diatur dalam pasal 29 UU Nomor 26 Tahun 2007 dan Permendagri Nomor 1 Tahun 2007. Bagi wilayah dengan ciri kekotaan kuat, senantiasa akan dihadapkan pada kondisi semakin menurunnya kualitas dan kuantitas RTH yang dapat dialokasikan, karena desakan pertumbuhan sarana dan prasarana kota, sebagai konsekuensi dari dinamika meningkatnya kebutuhan warga kota akan wadah kegiatan.

Tujuan pembangunan Ruang Terbuka Hijau (RTH) sebagai infrastruktur hijau di wilayah perkotaan adalah meningkatkan kualitas lingkungan hidup perkotaan yang nyaman, segar, indah dan bersih, sebagai sarana lingkungan perkotaan yang merupakan azas dari kota berkelanjutan (Kuswartojo T. 2006) Disamping itu bentuk RTH juga akan membuat keserasian lingkungan alami dan lingkungan binaan yang berguna untuk kepentingan masyarakat perkotaan.

Pertumbuhan penduduk perkotaan yang dari tahun ketahun semakin bertambah menjadikan semakin tinggi pula kebutuhan akan ruang untuk memenuhi fasilitas penduduk, seperti ruang untuk fasilitas perumahan, fasilitas perdagangan, fasilitas rekreasi dan berbagai fasilitas lainnya.

Pada tahun 2015 diperkirakan sebagian besar penduduk Indonesia akan tinggal diperkotaan, seperti terlihat pada Gambar 1 (Dimyati, 2010).

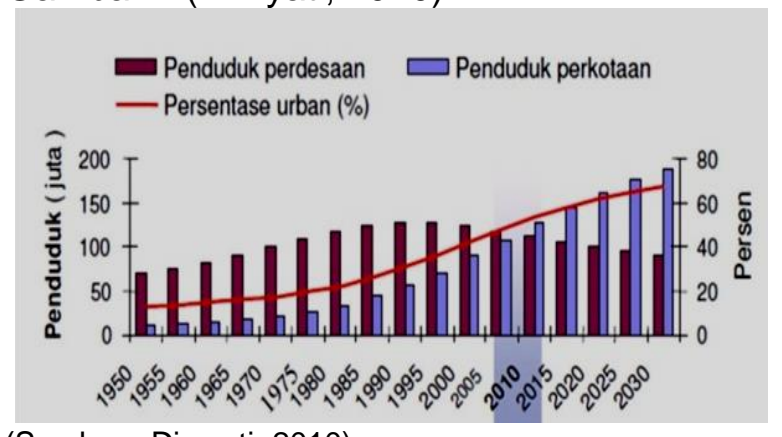

(Sumber : Dimyati, 2010)

Gambar 1. Grafik Perkembangan Perkotaan dan Perdesaan

Kondisi perkembangan penduduk yang demikian akan berdampak pada tingginya tekanan terhadap pemanfaat ruang kota 
(Alabi, 2009), akibatnya setiap jengkal lahan perkotaan, bahkan permukaan air seperti sungai, rawa dan pantai dipergunakan untuk membangun sarana dan prasarana kota, sehingga menimbulkan kecenderungan bahwa setiap pembangunan dan pemekaran kota, berusaha menuju maksimalisasi dari ruang kota, menuju minimalisasi dari ruang hijau kota dan menuju kehidupan artifisial yang sesungguhnya.

Kehidupan sosial perkotaan akan lebih baik dan sehat apabila tersedia ruang terbuka hijau yang cukup, tertencana dan teratur. Kondisi ini akan memberikan pertumbuhan jiwa yang sehat dan positif bagi setiap tingkat usia. Anak-anak dapat bermain ditaman dengan aman, bukan dijalan yang penuh bahaya. Remaja dapat berolah raga dan tumbuh dengan jiwa serta raga yang sehat pula. Masyarakat kota dapat berekreasi dan memulihkan kesegaran dan kebugaran, membangkitkan daya kreasi sehingga mereka bisa bekerja dengan penuh semangat untuk kesejahteraan keluarganya. Manusia menata lingkungan dengan penghijauan dan pertamanan, kemudian lingkungan akan memberi dukungan kembali bagi kepetingan kehidupan manusia yang lebih baik. RTH sangat berperan mengembalikan kreativitas kehidupan warga dari rutinitas dan kejenuhan dalam bekerja di perkotaan (Joga dan Ismaun, 2011).

Kota Makassar sebagai kota metropolitan dengan luas wilayah sebesar $17.577 \mathrm{Ha}$, sesuai sensus penduduk tahun 2015 berpenduduk 1.653 .386 jiwa, sudah masuk dalam kategori Kota Raya (metropolis) (Makassar Dalam Angka 2015). Berdasar pada kondisi perkembangan penduduk dan perkembangan aktivitas kota yang demikian pesat ini maka diperlukan RTH yang mampu menjalankan fungsi sosial dengan baik, sebagai salah satu instrument untuk menjaga kondisi warga kota tetap dalam suasana yang nyaman dan penuh kreativitas dalam bekerja sehingga kesejahteraan bisa terus meningkat. Untuk itu diperlukan kajian tentang identifikasi dan keterlaksanaan fungsi sosial RTH di kota Makassar, untuk mengetahui kondisi keterlaksanaannya, sehingga dapat terlihat RTH mana yang sudah berfungsi dengan baik dan yang belum baik.

\section{TINJAUAN TEORITIS}

Secara umum ruang terbuka publik (open spaces) di perkotaan terdiri dari ruang terbuka hijau dan ruang terbuka non-hijau. Ruang Terbuka Hijau (RTH) perkotaan adalah bagian dari ruang-ruang terbuka (open spaces) suatu wilayah perkotaan yang diisi oleh tumbuhan, tanaman dan vegetasi (endemik maupun introduksi) guna mendukung manfaat ekologis, sosial-budaya dan arsitektural yang dapat memberikan manfaat ekonomi (kesejahteraan) bagi masyarakatnya. Ruang terbuka non-hijau dapat berupa ruang terbuka yang diperkeras (paved) maupun Ruang Terbuka Biru (RTB) yang berupa permukaan sungai, danau, maupun areal-areal yang diperuntukkan sebagai genangan retensi (Dwiyanto, 2009).

Menurut Hakim (2012), Ruang terbuka hijau adalah area atau ruang kota yang tidak dibangun dan permukaannya dipenuhi oleh tanaman yang berfungsi melindungi habitat, sarana lingkungan, pengamanan jaringan prasarana, sumber pertanian, memperbaiki kualitas atmosfer dan menunjang kelestarian air dan tanah. Ruang terbuka hijau (Green Open spaces) di tengah-tengah ekosistem kota juga berfungsi untuk meningkatkan kualitas lansekap kota untuk keindahan dan kenyamanan, meningkatkan kualitas lingkungan dan pelestarian alam yang terdiri dari ruang linier atau koridor, ruang pulau atau oasis sebagai tempat pemberhentian (Spreigen dalam Hakim, 2012).

RTH diperkotaan digunakan juga sebagai tempat untuk evakuasi jika terjadi bencana alam. Bahkan pada daerah-daerah dengan intensitas bencana alam yang tinggi, RTH dirancang untuk dijadikan sebagai tempat penampungan sementara bagi warga kota yang mengalami bencana, misalnya gempa bumi dan kebakaran. Pada saat bencana terjadi, RTH dapat menjadi tempat yang aman untuk berbagai macam layanan darurat seperti penyediaan persediaan bantuan serta untuk mendirikan pusat komando pelayanan dan bantuan medis (Liangxin, dkk. 2012).

Secara fisik RTH dapat dibedakan menjadi RTH alami yang berupa habitat liar alami, kawasan lindung dan taman-taman nasional, maupun RTH non-alami atau binaan yang seperti taman, lapangan olah 
raga, dan kebun bunga. Dari segi fungsi $\mathrm{RTH}$ dapat berfungsi secara ekologis, sosial/budaya, arsitektural, dan ekonomi. Secara ekologis RTH dapat meningkatkan kualitas air tanah, mencegah banjir, mengurangi polusi udara, dan menurunkan temperatur kota. Bentuk-bentuk RTH perkotaan yang berfungsi ekologis antara lain seperti sabuk hijau kota, hutan kota, taman botani, sempadan sungai dan lain lain. Secara sosial-budaya keberadaan RTH dapat memberikan fungsi sebagai ruang interaksi sosial, sarana rekreasi, dan sebagai tetenger kota yang berbudaya. Bentuk RTH yang berfungsi sosial-budaya antara lain taman-taman kota, lapangan olah raga, kebun raya dan Tempat Pemakaman Umum.

Sementara itu secara struktur, bentuk dan susunan RTH dapat merupakan konfigurasi ekologis dan konfigurasi planologis. RTH dengan konfigurasi ekologis merupakan RTH yang berbasis bentang alam seperti kawasan lindung, perbukitan, sempadan sungai, sempadan danau, pesisir dan sebagainya. Sedangkan RTH dengan konfigurasi planologis dapat berupa ruangruang yang dibentuk mengikuti pola struktur kota seperti RTH perumahan, RTH kelurahan, RTH kecamatan, RTH kota maupun taman-taman regional dan nasional.

Berdasar pada uraian tersebut, RTH secara keseluruhan ruang terbuka hijau akan meningkatkan kualitas area kota yang pada akhirnya memicu peningkatan kualitas kesehatan warga kota, mempengaruhi gaya hidup, nilai dan tingkah laku dan akan meningkatkan penghargaan kepada lingkungan dan kemapanan kota.

\section{PERAN FUNGSI RTH}

Dalam perkotaan, RTH merupakan bagian atau salah satu subsistem dari sistem kota secara keseluruhan. RTH sengaja dibangun secara merata di seluruh wilayah kota untuk memenuhi berbagai fungsi dasar yang secara umum dibedakan menjadi :

\section{Fungsi bio-ekologis}

Fungsi ini memberi jaminan pengadaan RTH menjadi bagian dari sistem sirkulasi udara atau paru-paru kota, pengatur iklim mikro, agar sistem sirkulasi udara dan air secara alami dapat berlangsung lancar, sebagai peneduh, produsen oksigen, penyerap air hujan, penyedia habitat satwa, penyerap (pengolah) polutan media udara, air dan tanah, serta penahan angin.

\section{Fungsi Ekosistem}

Ekosistem perkotaan, produsen oksigen, tanaman berbunga, berbuah dan berdaun indah, serta bisa mejadi bagian dari usaha pertanian, kehutanan, dan lain-lain.

\section{Fungsi estetis}

Fungsi ini adalah meningkatkan kenyamanan, memperindah lingkungan kota baik dari skala mikro seperti halaman rumah, lingkungan permukiman, maupun makro atau lansekap kota secara keseluruhan. Mampu menstimulasi kreativitas dan produktivitas warga kota. Juga bisa berekreasi secara aktif maupun pasif, seperti, bermain, berolahraga, atau kegiatan sosialisasi lain, yang sekaligus menghasilkan keseimbangan kehidupan fisik dan psikis. Dapat tercipta suasana serasi, dan seimbang antara berbagai bangunan gedung, infrastruktur jalan dengan pepohonan hutan kota, taman kota, taman kota pertanian dan perhutanan, taman gedung, jalur hijau jalan, bantaran rel kereta api, serta jalur biru bantaran kali. Suatu studi tentang RTH terhadap nilai estetika adalah bahwa masyarakat bersedia untuk membayar keberadaan $\mathrm{RTH}$ karena memberikan rasa keindahan dan kenyamanan (Direktorat Jendral Penataan Ruang Departemen Pekerjaan Umum, 2006).

\section{Fungsi sosial, ekonomi dan budaya}

Mampu menggambarkan ekspresi budaya lokal, RTH merupakan media komunikasi warga kota, tempat rekreasi, tempat pendidikan, dan penelitian. Fungsi Sosial, RTH merupakan ruang yang dapat digunakan oleh manusia untuk melakukan aktivitas seperti berinteraksi dengan sesama atau mahluk lain atau melakukan kegiatankegiatan seperti bermain,olah raga, menunggu teman, belajar, atau hanya sekedar berjalan melewatinya.

Penataan vegetasi dalam RTH yang baik akan memberikan tempat interaksi sosial yang sangat produktif. Didalam RTH penyair atau seniman dapat merenung untuk menemukan inspirasi dan ilham. RTH dengan segala vegetasinya mengandung nilai-nilai ilmiah yang dapat menjadi laboratorium hidup untuk sarana pendidikan dan penelitian.

RTH diperkotaan digunakan juga sebagai tempat untuk evakuasi jika terjadi bencana 
alam. Bahkan pada daerah-daerah dengan intensitas bencana alam yang tinggi, RTH dirancang untuk dijadikan sebagai tempat penampungan sementara bagi warga kota yang mengalami bencana, misalnya gempa bumi dan kebakaran. Pada saat bencana terjadi, RTH dapat menjadi tempat yang aman untuk berbagai macam layanan darurat seperti penyediaan persediaan bantuan serta untuk mendirikan pusat komando pelayanan dan bantuan medis (Liangxin Fan, dkk. 2012).

\section{BENTUK DAN JENIS RTH DI PERKOTAAN}

Menurut Peraturan Menteri Dalam Negeri No.1 Tahun 2007 tentang Penataan Ruang Terbuka Hijau Kawasan Perkotaan, jenis RTHKP meliputi RTH jenis taman; RTH jenis hutan kota; RTH jenis bentang alam, cagar alam, kebun raya dan pemakaman; RTH jenis lapangan dan parkir, serta lahan pertanian; RTH jenis jalur, sempadan dan penyangga; RTH taman atap, taman dinding dan taman gantung.

\section{RTH jenis taman}

Taman kota merupakan ruang didalam kota yang ditata untuk menciptakan keindahan, kenyamanan, keamanan, dan kesehatan bagi penggunanya. Taman kota dilengkapi dengan beberapa fasilitas untuk kebutuhan masyarakat kota sebagai tempat rekreasi. Selain itu, taman kota difungsikan sebagai paru-paru kota, pengendali iklim mikro, konservasi tanah dan air, dan habitat berbagai flora dan fauna. Apabila terjadi suatu bencana, maka taman kota dapat difungsikan sebagai tempat posko pengungsian. Pepohonan yang ada dalam taman kota dapat memberikan manfaat keindahan, penangkal angin, dan penyaring cahaya matahari. Taman kota berperan sebagai sarana pengembangan budaya kota, pendidikan, dan pusat kegiatan kemasyarakatan. Pembangunan taman dibeberapa lokasi akan menciptakan kondisi kota yang indah, sejuk, dan nyaman serta menunjukkan citra kota yang baik.

Jenis taman yang lain adalah "kawasan taman wisata alam" merupakan kawasan pelestarian alam dengan tujuan utama untuk dimanfaatkan bagi kepentingan pariwisata dan rekreasi alam. Kawasan ini dikelola oleh pemerintah dan dikelola dengan upaya pengawetan keanekaragaman jenis tumbuhan dan satwa beserta ekosistemnya.

Selain taman tersebut diatas dikenal juga "Taman rekreasi" merupakan tempat rekreasi yang berada di alam terbuka tanpa dibatasi oleh suatu bangunan, atau rekreasi yang berhubungan dengan lingkungan dan berorientasi pada penggunaan sumber daya alam seperti air, hujan, pemandangan alam atau kehidupan di alam bebas. Kegiatan rekreasi dibedakan menjadi kegiatan yang bersifat aktif dan pasif. Kegiatan yang cukup aktif seperti piknik, olah raga, permainan, dan sebagainya melalui penyediaan saranasarana permainan.

Didalam lingkungan perumahan dan permukiman untuk menciptakan lingkungan yang didalamnya terdapat unsur-unsur yang bersifat alamiah, dikenal taman dengan klasifikasi yang lebih kecil dan diperuntukkan untuk kebutuhan rekreasi terbatas yang meliputi populasi terbatas/masyarakat sekitar. Taman lingkungan ini terletak disekitar daerah permukiman dan perumahan untuk menampung kegiatan-kegiatan warganya. Taman ini mempunyai fungsi sebagai paru-paru kota (sirkulasi udara dan penyinaran), peredam kebisingan, menambah keindahan visual, area interaksi, rekreasi, tempat bermain, dan menciptakan kenyamanan lingkungan. Pada lingkungan perkantoran dan gedung komersial dikenal juga taman dengan klasifikasi yang lebih kecil dan diperuntukkan untuk kebutuhan terbatas yang meliputi populasi terbatas/pengunjung. Taman ini terletak di beberapa kawasan institusi, misalnya pendidikan dan kantorkantor. Institusi tersebut membutuhkan ruang terbuka hijau pekarangan untuk tempat upacara, olah raga, area parkir, sirkulasi udara, keindahan dan kenyamanan waktu istirahat belajar atau bekerja.

\section{RTH jenis hutan kota}

Hutan kota adalah komunitas vegetasi berupa pohon dan asosiasinya yang tumbuh di lahan kota atau sekitarnya, berbentuk jalur, menyebar, atau bergerombol (menumpuk), strukturnya meniru (menyerupai) hutan alam, membentuk habitat yang memungkinkan kehidupan bagi satwa liar dan menimbulkan lingkungan sehat, suasana nyaman, sejuk, dan estetis. Berdasarkan PP No. 63 Tahun 2002, hutan kota didefinisikan sebagai suatu hamparan lahan yang bertumbuhan pohon- 
pohon yang kompak dan rapat di dalam wilayah perkotaan baik pada tanah negara maupun tanah hak, yang ditetapkan sebagai hutan kota oleh pejabat yang berwenang.

Bentuk lain dari hutan kota yang ada di perkotaan adalah "taman hutan raya" merupakan kawasan pelestarian alam untuk tujuan koleksi tumbuhan dan atau satwa yang alami atau bukan alami, jenis asli dan atau bukan asli, yang dimanfaatkan bagi kepentingan penelitian, ilmu pengetahuan, pendidikan, menunjang budidaya, budaya, pariwisata dan rekreasi.

Selain itu dikenal "hutan lindung/mangrove" merupakan kawasan hutan yang mempunyai fungsi sebagai perlindungan sistem penyangga kehidupan untuk mengatur tata air, mencegah banjir, mengendalikan erosi, mencegah intrusi air laut, dan memelihara kesuburan tanah. Selain itu, huta lindung/mangrove adalah sebidang RTH dikawasan perkotaan yang berfungsi sebagai kawasan lindung dengan kegiatan sangat ketat dan hati-hati, habitat satwa liar, penyangga lingkungan, dengan radius pelayanan untuk seluruh warga, luas areal sepanjang lahan tersedia, dilengkapi sarana dan fasilitas standar jalan setapak.

\section{RTH jenis bentang alam, cagar alam, kebun raya dan pemakaman}

$\mathrm{RTH}$ bentang alam adalah ruang terbuka yang tidak dibatasi oleh suatu bangunan dan berfungsi sebagai pengamanan keberadaan kawasan lindung perkotaan; pengendali pencemaran dan kerusakan tanah, air, dan udara, tempat perlindungan plasma nutfah dan keanekaragaman hayati, pengendali tata air dan sarana estetika kota.

Bentuk lain RTH dengan fungsi untuk perlindungan adalah kawasan cagar alam, yaitu kawasan suaka alam yang karena keadaan alamnya mempunyai kekhasan tumbuhan, satwa, dan ekosistemnya atau ekosistem tertentu yang perlu dilindungi dan perkembangannya berlangsung secara alami. Sesuai fungsinya, kawasan cagar alam ini dapat dimanfaatkan untuk penelitian dan pengembangan, ilmu pengetahuan, pendidikan, dan kegiatan penunjang budidaya.

Dikenal juga bentuk RTH sebagai "kebun raya", yaitu suatu area kebun yang ditanami berbagai jenis tumbuhan yang ditujukan terutama untuk keperluan penelitian. Selain itu, kebun raya juga digunakan sebagai sarana wisata dan pendidikan bagi pengunjung. Dua buah bagian utama dari sebuah kebun raya adalah perpustakaan dan herbarium yang memiliki koleksi tumbuh-tumbuhan yang telah dikeringkan untuk keperluan pendidikan dan dokumentasi

RTH lain dengan pemakain nama kebun adalah "kebun binatang" yaitu tempat hewan dipelihara dalam lingkungan buatan serta dipertunjukkan kepada publik. Selain menyuguhkan atraksi kepada pengunjung dan memiliki berbagai fasilitas rekreasi, kebun binatang juga mengadakan program program pembiakan, penelitian, konservasi, dan pendidikan.

Dalam bentuk yang lain dikenal RTH jenis pemakaman umum merupakan salah satu fasilitas sosial yang berfungsi sebagai tempat pemakaman bagi masyarakat yang meninggal dunia. Pemakaman umum juga memiliki fungsi lainnya seperti cadangan ruang terbuka hijau, daerah resapan air, dan paru-paru kota. Lahan pemakaman selain digunakan untuk tempat pemakaman, umumnya memiliki sedikit lahan untuk ruang terbangun dan sisanya ditanami berbagai jenis tumbuhan. RTH pemakaman perlu dikembangkan untuk mendukung kebutuhan akan lahan RTH yang semakin menyempit dan langka di wilayah perkotaan. Lahan pemakaman umum perlu ditata dengan baik untuk mencapai tujuannya sebagai daerah resapan air dan paru-paru kota. Ketersediaan sarana penunjang (jalan, tempat sampah, lampu taman, areal parkir, dan lainnya) di lokasi pemakaman juga merupakan hal yang perlu diperhatikan sehingga areal pemakaman tidak lagi berkesan menakutkan.

RTH jenis lapangan dan parkir serta lahan pertanian

Lapangan olahraga merupakan lapangan yang dibangun untuk menampung berbagai aktifitas olahraga seperti sepak bola, voli, atletik, dan golf serta saranasarana penunjangnya. Fungsi lapangan olahraga adalah sebagai wadah olahraga, tempat bermain, pertemuan, sarana interaksi dan sosialisasi, serta untuk meningkatkan kualitas lingkungan sekitarnya.

Selain lapangan olah olah raga juga dikenal "lapangan upacara", merupakan lapangan yang dibangun untuk kegiatan 
upacara. Umumnya kegiatan ini dilakukan di halaman perkantoran yang cukup luas dan lapangan olah raga.

Fasilitas kota dengan tujuan untuk area parkir merupakan unsur pendukung sistem sirkulasi kota yang dapat menambah kualitas visual lingkungan dengan mengkombinasikan dengan penanaman pohon yang berfungsi sebagai peneduh . Lahan parkir terbuka yang ada di perkantoran, hotel, restoran, pusat perbelanjaan, dan lainnya hendaknya ditanami dengan pepohonan agar tercipta lingkungan yang sejuk dan nyaman.

Pertanian kota adalah kegiatan penanaman, pengolahan, dan distribusi pangan di wilayah perkotaan. Kegiatan ini tentunya membutuhkan lahan yang cukup luas. Oleh karena itu, lahan ini biasanya jarang ditemui di wilayah perkotaan yang cenderung memiliki lahan yang sudah terbangun. Hasil pertanian kota ini menyumbangkan jaminan dan keamanan pangan yaitu meningkatkan jumlah ketersediaan pangan masyarakat kota serta menyediakan sayuran dan buah-buahan segar bagi masyarakat kota. Selain itu, pertanian kota juga dapat menghasilkan tanaman hias dan menjadikan lahan-lahan terbengkalai kota menjadi indah. Dengan pemberdayaan masyarakat penggarap maka pertanian kota pun menjadi sarana pembangunan modal sosial.

\section{$R T H$ jenis jalur, sempadan dan penyangga}

Pengamanan area tertentu bisa juga dilakukan dalam bentuk RTH, seperti SUTT (Saluran Udara Tegangan Tinggi) dan SUTET (Saluran Udara Tegangan Ekstra Tinggi) adalah sistem penyaluran listrik yang ditujukan untuk menyalurkan energi listrik dari pusat-pusat pembangkit yang jaraknya jauh menuju pusat-pusat beban sehingga energi listrik bisa disalurkan dengan efisien. Daerah sekitarnya hendaklah tidak dijadikan daerah terbangun, tapi dijadikan RTH jalur hijau. RTH ini berfungsi sebagai pengamanan, pengendalian jaringan listrik tegangan tinggi, dan mempermudah dalam melakukan perawatan instalasi.

Jenis RTH jalur yang lain adalah "jalur hijau jalan", yaitu pepohonan, rerumputan, dan tanaman perdu yang ditanam pada pinggiran jalur pergerakan di samping kirikanan jalan dan median jalan. RTH jalur pengaman jalan terdiri dari RTH jalur pejalan kaki, taman pulau jalan yang terletak di tengah persimpangan jalan, dan taman sudut jalan yang berada di sisi persimpangan jalan. Median jalan adalah ruang yang disediakan pada bagian tengah dari jalan untuk membagi jalan dalam masing-masing arah yang berfungsi mengamankan ruang bebas samping jalur lalu lintas.

RTH juga bisa difungsikan sebagai pembatas dari sungai, danau, waduk, situ, pantai, dan mata air atau bahkan kawasan limitasi terhadap penggunaan lahan disekitarnya yang dikenal dengan istilah "sempadan". Selain untuk pembatas, fungsi lain dari sempadan adalah untuk penyerap aliran air, perlindungan habitat, dan perlindungan dari bencana alam. Sempadan sungai adalah kawasan sepanjang kiri kanan sungai termasuk sungai buatan/kanal/saluran irigasi primer yang mempunyai manfaat penting untuk mempertahankan kelestarian fungsi sungai, mengamankan aliran sungai, dan dikembangkan sebagai area penghijauan. Kawasan sekitar waduk/danau/situ adalah kawasan di sekeliling waduk/danau/situ yang mempunyai manfaat penting untuk mempertahankan kelestarian fungsi waduk/danau/situ.

Kawasan vital seperti bandara karena lintasan untuk terbang dan pendaratan memerlukan pengamanan, maka dibuatlah kawasan penyangga atau daerah penyangga, yaitu wilayah yang berfungsi untuk memelihara dua daerah atau lebih untuk beberapa alasan. Kawasan ini dalam bentuk hamparan yang ditanami rumput pada sekitar area lintasan penerbangan dan pendaratan. Sedangkan kawasan diluar daerah lintasan yang yang mengelilingi bandara dan ditanami pohon biasa disebut buffer zone.. Daerah penyangga ini berfungsi untuk peredam kebisingan, melindungi lingkungan, menjaga area permukiman dan komersial di sekitarnya apabila terjadi bencana, dan lainnya.

\section{RTH taman atap, taman dinding dan taman gantung}

Taman atap adalah taman yang memanfaatkan atap atau teras rumah atau gedung sebagai lokasi taman. Taman ini berfungsi untuk membuat pemandangan lebih asri, teduh, sebagai insulator panas, menyerap gas polutan, mencegah radiasi ultraviolet dari matahari langsung masuk ke 
dalam rumah, dan meredam kebisingan. Taman atap ini juga mampu mendinginkan bangunan dan ruangan dibawahnya sehingga bisa lebih menghemat energi seperti pengurangan pemakaian AC. Tanaman yang sesuai adalah tanaman yang tidak terlalu besar dengan sistem perakaran yang mampu tumbuh pada lahan terbatas, tahan hembusan angin, dan tidak memerlukan banyak air. Komponen bangunan yang memungkinkan dipergunakan sebagai media untuk RTH adalah dinding bangunan. Selain itu media dalam bentuk digantung bisa juga dipergunakan untuk penghijauan kota. Jalur tengah dan pinggir jalan memungkinkan untuk

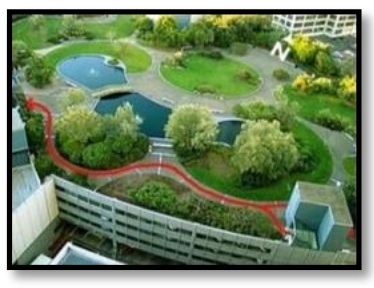
inplementasi model

taman gantung. Model ini sangat berpotensi untuk pembentukan citra kota terutama dalam bentuk tanaman berbunga. Untuk kondisi kota yang sudah padat dan lahan untuk pembangunan RTH sangat susah didapat, maka taman atap dan taman dinding merupakan solusi yang bisa ditempuh dalam menambah RTH di wilayah perkotaan. Contoh penerapan taman atap di perkotaan seperti gambar 1 berikut.

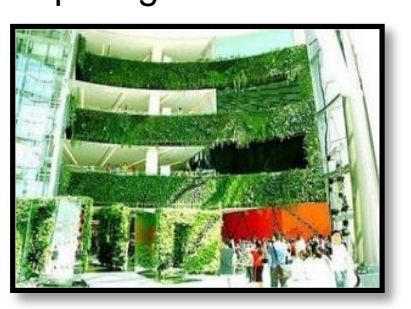

\section{(Sumber}

http:wordpress.com, Diakses 20 Desember 2016)

Gambar 2. Taman Dinding dan Taman Atap.

Secara fisik RTH dapat dibedakan menjadi RTH alami berupa habitat liar alami, kawasan lindung dan taman-taman nasional serta RTH non alami atau binaan seperti taman, lapangan olahraga, pemakaman atau jalur-jaur hijau jalan. Dilihat dari fungsi RTH dapat berfungsi ekologis, sosial budaya, estetika, dan ekonomi. Secara struktur ruang, RTH dapat mengikuti pola ekologis (mengelompok, memanjang, tersebar), maupun pola planologis yang mengikuti hirarki dan struktur ruang perkotaan. Dari segi kepemilikan, RTH dibedakan ke dalam RTH publik dan RTH privat.

\section{METODE PENELITIAN}

Penelitian ini adalah penelitian survei dengan analisis diskriptif. Penelitian ini dilaksanakan di Kota Makassar. Populasi dalam penelitian ini adalah seluruh RTH di Kota Makassar dan pengambilan sampel dilakukan dengan teknik bertujuan (purposive sampling), yaitu teknik sampling yang tidak berdasarkan strata, random, tetapi berdasarkan adanya tujuan yang hendak dicapai dengan sampel tersebut. Untuk itu sengaja dipilih, RTH Lapangan Kompleks Karebosi, RTH Taman Macan, RTH Taman Pattimura, RTH Taman Hasanuddin dan RTH Lapangan Hasanuddin merupakan RTH yang merepresentasikan RTH pusat kota serta RTH Lapangan Emmy Saelan dan RTH Lapangan Bumi Tamalanrea Permai sebagai refresentasi RTH di luar pusat kota.

Data dikumpulkan dengan teknik ovservasi. Obsesrvasi dilakukan peneliti dengan mengamati lansung RTH dilapangan, kemudian mendokumentasikan jenis fasilitas yang ada didalamnya. Juga akan diamati aktivitas yang terjadi berdasarkan tiap fasilitas yang ada. Pendokumentasian data dilakukan baik dalam bentuk catatan maupun dengan pemotretan. Disamping itu dilakukan juga wawancara dengan aparat terkait untuk memperoleh gambaran kondisi RTH dan perkembangannya di Kota Makassar. Selanjutnya dilakukan studi literatur dan kepustakaan, sebagai acuan normatif dan dasar analisis teoritis terutama yang berkaitan dengan RTH.

Analisis data dilakukan dengan teknik tabel skalogram yang akan memperlihatkan jenis RTH dan fungsi yang bisa terlaksana berdasarkan fasilitas yang ada dalam RTH. Pada tabel skalogran ini juga akan memperlihatkan tingkat intensitas keterlaksanaan fungsi berdasarkan banyaknya fasilitas yang ada demikian juga dengan tingkat kontinyuitas dari masingmasing keterlaksanaan fungsi.

Berdasarkan hasil tabel skalogram akan dihitung COR (Coeffisient of Refroducibility) yaitu angka persentase yang dari hasil bagi antara jumlah sel tabel yang terisi dengan jumlah sel tabel keseluruhan. Dalam bentuk persamaan dapat diagambarkan sebagai berikut :

COR $=\frac{A}{Q} \times 100$

$\mathrm{COR}=$ Persentase cofisien refroducibility 
A = Jumlah sel yang terisi

$\mathrm{Q} \quad=$ Jumlah sel keseluruhan

Teknik skalogram merupakan salah satu alat analisis yang dipakai untuk menilai tingkat hirarki kelengkapan fasilitas suatu unit lingkungan. Teknik analisis skalogram ini banyak dipakai oleh para geograf, demograf dan perencana untuk menganalisis tingkat hirarki ketersediaan fasilitas diperkotaan (Rondinelli, 1985).

\section{Definisi Operasional}

Jenis RTH adalah suatu area dikawasan perkotaan yang diatasnya tumbuh tanaman, baik disengaja maupun tumbuh secara alamiah, ada dalam bentuk taman, jalur, lapangan, pemakaman dan dalam bentuk yang lain.

Keterlaksanaan fungsi sosial RTH adalah peran yang diembang oleh RTH dalam mewadahi aktifitas warga kota berdasarkan fasilitas yang ada didalamnya, bisa dalam bentuk olah raga, duduk santai, ngobrol atau bermain bersama dengan anak-anak.

\section{HASIL DAN PEMBAHASAN}

\section{Jenis RTH Di Kota Makassar}

Berdasarkan hasil survei lapangan pada 7 lokasi RTH di Kota Makassar, diperoleh jenis RTH seperti pada tabel 1.

\begin{tabular}{|c|c|c|c|}
\hline Nama RTH & Lokasi & Jenis & $\begin{array}{l}\text { Luas } \\
\text { (M2) }\end{array}$ \\
\hline $\begin{array}{l}\text { RTH Kompleks } \\
\text { Lap. Karebosi }\end{array}$ & \multirow{5}{*}{$\begin{array}{c}\text { Kecamatan } \\
\text { Ujung } \\
\text { Pandang }\end{array}$} & Lapangan & 73.000 \\
\hline $\begin{array}{l}\text { RTH Taman } \\
\text { Macan }\end{array}$ & & Taman & 10.638 \\
\hline $\begin{array}{c}\text { RTH Taman } \\
\text { Pattimura }\end{array}$ & & Taman & 1.601 \\
\hline $\begin{array}{l}\text { RTH Taman } \\
\text { Hasanuddin }\end{array}$ & & Taman & 7.050 \\
\hline $\begin{array}{c}\text { RTH Lapangan } \\
\text { Hasanuddin }\end{array}$ & & Lapangan & 19.500 \\
\hline $\begin{array}{l}\text { RTH Lapangan } \\
\text { Emmy Saelan }\end{array}$ & $\begin{array}{c}\text { Kecamatan } \\
\text { Rappocini }\end{array}$ & Lapangan & 12.850 \\
\hline $\begin{array}{c}\text { RTH Lapangan } \\
\text { BTP }\end{array}$ & $\begin{array}{l}\text { Kecamatan } \\
\text { Tamalanrea }\end{array}$ & Lapangan & 20.000 \\
\hline
\end{tabular}

Terlihat pada tabel 1 dari tujuh RTH yang menjadi sampel penelitian terdapat empat $\mathrm{RTH}$ dalam bentuk lapangan dan tiga RTH dalam bentuk taman. Kemudian jika dilihat lokasi keberadaanya ada lima RTH yang berlokasi di Kecamtan Ujung Pandang dan masing-masing satu lokasi berada di Kecamatan Rappocini dan Kecamatan
Tamalanrea. Kecamatan Ujung Pandang merupakan kecamatan yang berada di pusat kota dan inti Kota Makassar yang merupakan cikal bakal perkembangan awal Kota Makassar moderen yang kita kenal sekarang dimulai dari kecamatan ini.

RTH yang berada dalam kecamatan ini merupakan RTH yang ada sejak pemerintahan kolonial Belanda, dan dibangun sebagai sarana kelengkapan kota mengikuti pola perkembangan kota yang ada di negara-negara Eropa terutama Inggris yang terkenal dengan konsep kota tamannya. Terlihat jelas RTH yang ada di Kecamatan Ujung Pandang terstruktur mengikuti pola perkembangan planologis kota.

Berdasarkan luasan masing-masing RTH terlihat bahwa, Kompleks Lapangan Karebosi merupakan RTH terluas dan memang RTH ini merupakan RTH tingkat kota dan terletak di kilometer satu Kota Makassar. RTH Lapangan Bumi Tamalanrea Permai (BTP) merupakan RTH dengan luasan terluas kedua. RTH ini merupakan fasilitas yang disediakan oleh pengembang perumahan BTP bagi warga yang telah bermukim di kawasan ini dalam menyalurkan aktivitasnya dalam bidang olah raga. $\mathrm{RTH}$ yang menempati posisi ketiga adalah RTH Lapangan Hasanuddin. RTH ini terletak dikawasan militer dan terlihat bahwa RTH ini banyak dipergunakan oleh kalangan militer untuk membina kesegaran jasmani. RTH dengan luasan terkecil adalah Taman Pattimura yang terletak berdampingan dengan RTH Taman Macan.

\section{Keterlaksanaan Fungsi Sosial}

Berdasarkan hasil survei terhadap keterlaksanaan fungsi sosial RTH pada tujuh lokasi yang menjadi sampel tergambar seperti pada tabel skalogram pada tabel 2 .

Pada tabel 2 terlihat bahwa tingkat keterlaksanaan fungsi sosial RTH di Kota Makassar berdasarkan sampel dan variabel yang dilihat sebesar 35 persen. Angka ini menunjukkan dibawah 50 persen, yang bisa diartikan keterlaksanaan fungsi sosial RTH di Kota Makassar termasuk rendah.

Jika dilihat keterlaksanaan fungsi berdasarkan unit RTH, maka RTH Kompleks Lapangan Karebosi merupakan RTH dengan tingkat keterlaksanaan fungsi paling tinggi atau rangking pertama, disusul RTH Lapangan Hasanuddin pada rangking kedua, 
RTH Taman Macan pada rangking ketiga, sedangkan RTH dengan tingkat keterlaksanaan fungsi paling rendah adalah RTH Taman Pattimura.

Jika berdasarkan aktivitas, mayoritas fungsi sosial terlaksana dalam kegiatan olah raga. Di RTH Kompleks Lapangan Karebosi aktivitas olah raga yang dominan adalah sepak bola dan jalan cepat. Aktivitas sepak bola dan jalan cepat berlansung pagi dan sore setiap hari. Jumlah orang yang beraktivitas jalan cepat di RTH ini setiap hari berkisar 100 sampai 150 orang, untuk hari libur Sabtu dan Minggu mencapai dua kali lipat.

Tabel

2.

Skalogram

\begin{tabular}{|c|c|c|c|c|c|c|c|c|c|c|c|c|c|c|c|c|c|c|c|c|c|c|c|c|c|c|c|c|c|}
\hline No & Nama RTH & 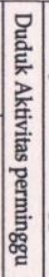 & 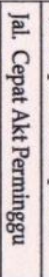 & 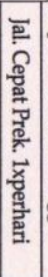 & 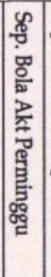 & 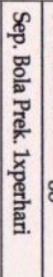 & 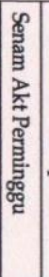 & 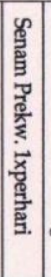 & 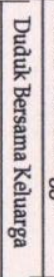 & 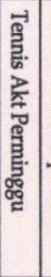 & 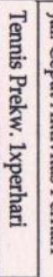 & 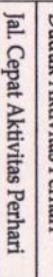 & 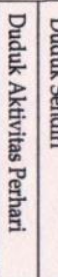 & 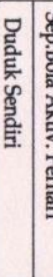 & 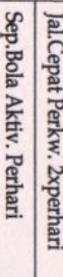 & 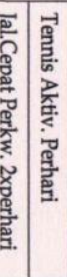 & 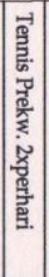 & 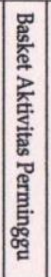 & 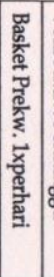 & 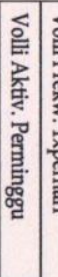 & 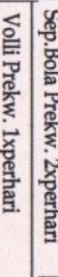 & 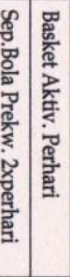 & 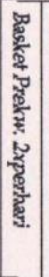 & 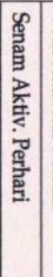 & 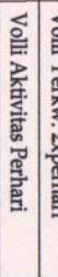 & 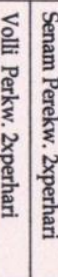 & 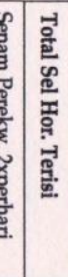 & 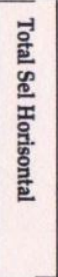 & 茯 \\
\hline 1 & $\begin{array}{l}\text { RTH Komp. } \\
\text { Lap.Karebosi }\end{array}$ & $x$ & $x$ & $x$ & $x$ & $x$ & $x$ & $x$ & $x$ & $x$ & $x$ & $\mathbf{x}$ & $\mathbf{x}$, & $\mathbf{x}$, & $x \quad x$ & $x \quad x$ & $x$ & $x$ & $x$ & $\mathbf{x}$ & $x \quad x$ & $x \quad x$ & $x$ & $x$ & - & - & $\begin{array}{l}- \\
-\end{array}$ & 28 & I \\
\hline 2 & $\begin{array}{l}\text { RTH Lap. } \\
\text { Hasanuddin }\end{array}$ & - & $x$ & $x$ & $x$ & $x$ & - & - & - & $x$ & $x$ & $x$ & -1 & -1 & $x$ & $x$ & $x$ & $x$ & $x$ & - & - & - & - & - & - & - & 12 & 28 & II \\
\hline 3 & $\begin{array}{l}\text { RTH Taman } \\
\text { Macan }\end{array}$ & $x$ & $x$ & $x$ & - & - & $x$ & $x$ & $x$ & - & - & $\mathbf{x}$ & $x$ & $\mathbf{x}$ & $-x$ & $x-$ & - & - & - & - & - & - & - & - & - & - & 10 & 28 & III \\
\hline 4 & $\begin{array}{l}\text { RTH Lap. } \\
\text { Emmy Saelan }\end{array}$ & $x$ & $x$ & $x$ & $x$ & $x$ & $x$ & $x$ & $x$ & - & - & - & - & - & - & - & - & - & - & - & - & - & - & - & - & - & 8 & 28 & IV \\
\hline 5 & $\begin{array}{l}\text { RTH Lapangan } \\
\text { BTP }\end{array}$ & - & $x$ & $x$ & $x$ & $x$ & $x$ & $x$ & - & $x$ & $x$ & - & -1 & - & - & - & - & - & - & - & - & - & - & - & - & - & 8 & 28 & IV \\
\hline 6 & $\begin{array}{l}\text { RTH Taman } \\
\text { Hasanuddin }\end{array}$ & $x$ & - & - & - & - & - & - & - & $x$ & $x$ & - & $\mathbf{x}$ & $\mathbf{x}$ & - & - & - & - & - & - & - & - & - & - & - & - & 5 & 28 & V \\
\hline 7 & $\begin{array}{l}\text { RTH Taman } \\
\text { Pattimura }\end{array}$ & $x$ & - & - & - & - & - & - & $x$ & - & - & - & - & - & - & - & - & - & - & - & - & - & - & - & - & - & 2 & 28 & VI \\
\hline Tot & Sel Ver. Terisi & 5 & 5 & 5 & 5 & 4 & 4 & 4 & 4 & 4 & 4 & 3 & 3 & 3 & 2 & 2 & 2 & 2 & 2 & 1 & 1 & $1 \mid 1$ & 1 & 1 & 0 & \begin{tabular}{l|l}
0 & 0
\end{tabular} & \begin{tabular}{l|l}
0 & 70
\end{tabular} & & \\
\hline & tal Sel Vertikal & 7 & 7 & 7 & 7 & 7 & 7 & 7 & 7 & 7 & 7 & 7 & 7 & $7:$ & \begin{tabular}{l|l}
7 & 7 \\
\end{tabular} & 7 & 7 & 7 & 7 & 7 & 77 & \begin{tabular}{l|l}
7 & 7 \\
\end{tabular} & 7 & 7 & 7 & $7 \quad 7$ & 7 & 196 & \\
\hline To & al Sel Terisi $=A$ & \multicolumn{28}{|c|}{70} \\
\hline & Cotal Sel $=Q$ & \multicolumn{28}{|c|}{196} \\
\hline & $R=(A / Q) \times 100$ & \multicolumn{28}{|c|}{35 Persen } \\
\hline
\end{tabular}

(Sumber: Hasil Analisis, 2016)

Di RTH Lapangan Hasanuddin aktivitas yang dominan adalah sepak bola, kemudian tennis dan jalan cepat. Aktivitas sepak bola berlansung disore hari demikian juga aktivitas pada lapangan tennis. Untuk hari minggu aktivitas tennis bisa berlangsung mulai pagi hari. Kegiatan jalan cepat pada RTH Lapangan Hasanuddin berlangsung setiap pagi hari dengan jumlah orang terbatas atau kurang dari 50 orang, tidak seramai aktivitas jalan cepat pada RTH Kompleks Lapangan Karebosi. Fasilitas olah raga dengan frekuensi kegiatan yang minimal di Lapangan karebosi adalah olah raga volli.

Di RTH Taman Macan aktivitas yang dominan terlaksana disini adalah aktivitas olah raga jalan cepat yang berlangsung setiap pagi dan sore. RTH ini diminati juga oleh warga kota untuk bersantai bersama keluarga terutama pada hari minggu. Kegiatan aktivitas non olah raga/bersantai disini berlansung karena fasilitas yang ada memungkinkan. Didalam RTH ini terdapat tempat duduk yang memadai, terdapat kolam dan air mancur serta terdapat berbagai tanaman berbunga dengan penataan relatif lebih baik dibanding dengan RTH lain. Pada hari minggu berlangsung olah raga senam yang dilaksanakan di pelataran RTH.

Di RTH Lapangan Emmy Saelan aktivitas dominan adalah olah raga sepak bola dan kegiatan jalan cepat dan senam yang terselenggara terutama pada hari minggu. Pola kegiatan ini juga berlangsung pada RTH Lapangan BTP Tamalanrea. Kedua RTH ini masih memerlukan penataan dan kelengkapan sarana untuk bisa menjadi $\mathrm{RTH}$ yang lebih refresentatif, dalam melayani aktivitas dari warga kompleks perumahan BTP.

\section{KESIMPULAN DAN SARAN}


Berdasarkan hasil penelitian dan pembahasan, dapat ditarik kesimpulan dan saran sebagai berikut :

Mayoritas RTH di Kota Makassar berdasarkan sampel yang diambil masuk dalam kategori jenis lapangan. Dari 7 lokasi RTH yang diamati empat berjenis lapangan dan tiga jenis taman. Mayoritas RTH yang ada terkonsentrasi di Kecamatan Ujung Pandang atau berada di pusat kota. Tingkat keterlaksanaan fungsi sosial RTH di Kota Makassar berdasarkan analisis skalogram berada pada angka 0.42 persen, atau masih tergolong rendah. Fungsi sosial RTH yang terlaksana lebih didominasi kegiatan olah raga. Hal ini sesuai dengan jenis $\mathrm{RTH}$ yang ada yang mayoritas dalam bentuk lapangan.

Agar aktivitas RTH tidak didominasi oleh kegiatan olah raga, maka diperlukan revitalisasi RTH yang ada dengan menambah sarana kelengkapan baik dalam bentuk aneka tanaman pelindung dan berbunga, maupun dalam bentuk sarana kelengkapan berupa wahana mainan anakanak, tempat duduk serta penataan perletakannya yang membuat orang tertarik mengunjunginya.

\section{DAFTAR PUSTAKA}

Alabi M.O. 2009. Revitalizing Urban Public Open Space, Through, Vegetative Engclave in Lakoja, Nigeria. Journal of Geographic and Regional Planning, Vol.2(3),pp.051-054, March, 2009.

Dimyati (2010). Mengatasi Backlog Perumahan Bagi Masyarakat Perkotaan. Makalah dalam Seminar Perumahan, Jakarta.

Dwiyanto, Agung. 2009. Kuantitas dan Kualitas Ruang Terbuka Hijau (RTH) di Permukiman Kota. Jurnal Nasional Arsitektur.

Fan L, Xue S dan Liu G. (2012). Patterns and Its Disaster Shelter of Urban Green Space. Empirical Evidence from Jiaozuo City, Cina. Aprican.

Hakim R. (2012). Komponen Perancangan Arsitektur Lansekap, Prinsip Unsur dan Aplikasi Desain. Bumi Aksara Jakarta.

Joga N, dan Ismaun I. 2011. RTH 30\%, Resolusi (Kota) Hijau. PT. Gramedia Pustaka Utama, Jakarta.

Kuswartojo T. (2006), Azas Kota Berkelanjutan Di Indonesia dan Penerapan. Junal Teknik Lingkungan P3TL-BPPT, 7 (1): 1-6.

2006. Ruang Terbuka Hijau, sebagai Unsur Utama Tata Ruang Kota. Departemen Pekerjaan Umum, Direktorat Jenderal Penataan Ruang, Jakarta.

Undang-Undang Nomor 26 Tahun 2007 Tentang Penataan Ruang.

Peraturan Menteri Dalam Negeri Nomor 1 Tahun 2007 Tentang Penataan Ruang Terbuka Hijau Kawasan Perkotaan. 